\title{
Erratum: Biosimilar FSH preparations- are they identical twins or just siblings?
}

\author{
Raoul Orvieto ${ }^{1,2^{*}}$ and David B. Seifer ${ }^{3}$
}

\section{Erratum}

The original version of this article [1] unfortunately contained an error.

The following lines regarding RCT [23] in Table 1: '... the Gonal-f group achieved non significantly more oocytes of (10.7 vs 10.6, respectively), despite lower peak E2 levels and lower cancellation rate (7704 vs $8982 \mathrm{pmol} / \mathrm{L}$ and $0.8 \%$ vs $2.0 \%$, respectively) with...' has been corrected.

This has been corrected to: '...the Gonal-f group achieved non significantly less oocytes (10.4 vs 10.7 , respectively), with lower peak E2 levels and lower cancellation rate (7704 vs $8982 \mathrm{pmol} / \mathrm{L}$ and $8.9 \%$ vs $11.2 \%$, respectively) with the consequent decreased incidence of OHSS...".

\footnotetext{
Author details

${ }^{1}$ Department of Obstetrics and Gynecology, Infertility and IVF Unit, Chaim Sheba Medical Center (Tel Hashomer), Ramat Gan 52621, Israel. ${ }^{2}$ Sackler Faculty of Medicine, Tel Aviv University, Tel Aviv, Israel. ${ }^{3}$ Department of Obstetrics and Gynecology, Division of Reproductive Endocrinology and Infertility, Dartmouth-Hitchcock Medical Center, Geisel School of Medicine at Dartmouth, Lebanon, NH, USA.
}

Received: 3 August 2016 Accepted: 31 August 2016

Published online: 15 September 2016

\section{Reference}

1. Orvieto R, Seifer DB. Biosimilar FSH preparations- are they identical twins or just siblings? Reprod Biol Endocrinol. 2016;14:32. doi:10.1186/ s12958-016-0167-8.

\footnotetext{
* Correspondence: raoul.orvieto@sheba.health.gov.il

'Department of Obstetrics and Gynecology, Infertility and IVF Unit, Chaim

Sheba Medical Center (Tel Hashomer), Ramat Gan 52621, Israel

${ }^{2}$ Sackler Faculty of Medicine, Tel Aviv University, Tel Aviv, Israel

Full list of author information is available at the end of the article
}

Submit your next manuscript to BioMed Central and we will help you at every step:

- We accept pre-submission inquiries

- Our selector tool helps you to find the most relevant journal

- We provide round the clock customer support

- Convenient online submission

- Thorough peer review

- Inclusion in PubMed and all major indexing services

- Maximum visibility for your research

Submit your manuscript at www.biomedcentral.com/submit 